CARPATHIAN JOURNAL OF FOOD SCIENCE AND TECHNOLOGY

journal homepage: http://chimie-biologie.ubm.ro/carpathian_journal/index.html

\title{
EFFECT OF UV-C IRRADIATION ON MICROBIAL LOAD AND PHENOLIC CONTENT OF POTATO TUBERS AND SLICES
}

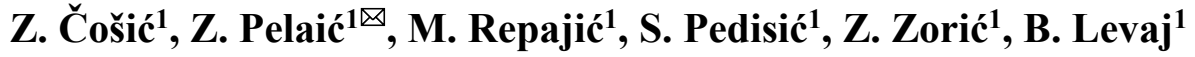 \\ ${ }^{1}$ Faculty of Food Technology and Biotechnology, University of Zagreb, Pierottijeva 6, 10000 Zagreb, Croatia

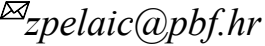 \\ https://doi.org/10.34302/crpifst/2021.13.3.2 \\ Article history: \\ Received: \\ 22 October 2020 \\ Accepted: \\ 25 July 2021 \\ Keywords: \\ UV-C light; \\ Potato tubers; \\ Sliced potato; \\ Microbiology; \\ Phenolic content.

\section{ABSTRACT} \\ The effect of different UV-C irradiation doses on tubers and sliced potato \\ (with or without sample's turning during irradiation) on aerobic mesophilic \\ bacteria count (AMB), phenolic composition and visual appearance of \\ potatoes after $24 \mathrm{~h}$ storage at $10^{\circ} \mathrm{C}$ was examined. Doses of UV-C irradiation \\ were $1.08,2.70,5.40$ and $10.08 \mathrm{~kJ} \mathrm{~m}^{-2}$ for tubers and $1.08,1.62$ and $2.70 \mathrm{~kJ}$ \\ $\mathrm{m}^{-2}$ for potato slices. UV-C irradiation, particularly with slice turning, caused \\ the significant reduction of the AMB in comparison with untreated potatoes \\ in accordance to the irradiation dose. Further, it caused a significant increase \\ of phenolic substances in all samples, especially in tubers, although inversely \\ to the irradiation dose. Independently of the applied treatment, chlorogenic \\ acid, caffeic acid and rutin were identified in all samples where chlorogenic \\ acid was predominant. Generally, the turning of potatoes during irradiation \\ had a significant effect on the increase of chlorogenic acid in potato slices. \\ Samples with higher phenolic content were more prone to browning. Based \\ on all obtained results UV-C treatment of potato slices with dose $1.62-2.70$ \\ $\mathrm{kJ} \mathrm{m}^{-2}$ and with turning could be recommended as the most promising \\ treatment.
}

\section{Introduction}

Nowadays consumers prefer minimally processed, highly nutritional, safe, and attractive food, in the same time being convenient for easy and fast use and meals preparation, e.g., ,ready to eat" or ,ready to use" foods. Therefore, popularity and market demand for minimally processed, fresh-cut fruits and vegetables (FCFV) have been constantly increased. Minimal processing includes operations such as peeling and cutting, which cause tissue damage, thus lead to the quality deterioration, and reduced shelf-life (Rico et al., 2007). Consequently, fresh-cut products have shorter shelf-life compared to the intact fruits or vegetables (Gutierrez et al., 2017), where potato presents an excellent example regarding this matter. The loss of the natural protection as well as the high water content along with the presence of several nutrients are responsible for the main undesirable alterations in FCFV such as increased metabolic activity, enzymatic browning and microbiological growth (Gutierrez et al., 2009), which additionally could raise the risk of foodborne diseases (Manzocco et al., 2011). The main challenge of minimal processing industry is to obtain a safe and high-quality product as well as its prolonged shelf-life (Gutierrez et al. 2017), therefore the interest for the application of new efficient technologies is being raised (Gonzales-Aguilar et al., 2010). Currently, the main tools in maintaining the quality and safety of FCFV are the utilization of appropriate packaging in modified atmosphere and refrigeration (Gutierrez et al., 2017), but various approaches have been examined to improve the shelf-life of FCFV, including many non-thermal 
technologies (Ma et al., 2017). Primary advantages of ultraviolet irradiation (UV-C), responsible for considering it as the promising non-thermal technique, are its efficacy on various types of microorganisms, no residue in the treated food, easy manipulation and not too large equipment investments (Yaun et al., 2004; Ma et al. 2017; Koutchama, 2019). UV-C irradiation can reduce the microorganism's growth, control browning (Guan et al. 2013), and inhibits peroxidase (POD) activity (Teoh et al. 2016) as well as increases the resistance to rot and extend the shelf life (Jakubowski, 2019). Further, UV-C treatment has been associated with an increase in bioactive compounds such as vitamins, carotenoids and phenolic compounds in several tested fruits and vegetables, e.g., tomatoes (Jagadeesh et al., 2011; Maharaj et al. 2014), strawberries (Erkan et al., 2008; Xie et al., 2014), carrots (Alegria et al., 2012) and broccoli (Costa et al., 2006). However, several authors observed the UV-C negative influence with elongated UV-C exposure time, e.g., browning in pineapple slices during storage and decrease of vitamin C content (Pan \& Zu, 2012) as well as plant tissue damage, increase stress and respiration rate (Rico et al., 2007). Hence, the use of non-ionizing, germicidal UV-C irradiation can be effective if the optimal radiation dose for each product is previously examined and determined.

Therefore, the aim of this study was to examine the influence of germicidal UV-C irradiation dose and treatment conditions on microbial load, phenolic compounds and susceptibility to browning of potato tubers and slices.

\section{Materials and methods}

\subsection{Samples}

Tubers of cultivar Birgit (Solanum tuberosum L.), grown in Slavonia region (Croatia) during 2018 were used for the experiment. Prior to analysis, tubers were stored in dark room at $8{ }^{\circ} \mathrm{C}$ with a relative humidity approximately $100 \%$.

\subsubsection{Sample preparation}

Undamaged potato tubers were selected, washed with tap water and dried with paper towels. One batch was peeled, again washed, surface moisture was removed by paper towels and then cut into slices $0.4 \mathrm{~cm}$ wide (potato slices, PS) using an electric cutter (SFS 1001 GR, Sencor, Czech Republic). Prepared samples of potato tubers (PT) and PS were further subjected to UV-C treatment in an UV-C chamber (UVpro EKB 100, assembled by Aura Steril, Jalkovec, Varaždin, Croatia) equipped with 2 pairs of UV-C lamps (UVpro, 4xHNSL $24 \mathrm{~W})$ situated above and below perforated shelf (Figure 1). The dose of irradiation was measured using UV-C radiometer (UVCpro UVC-LOG, Orca GmbH, Germany). PT were exposed to UV-C irradiation for 0 (control), 2, 5, 10 and 20 $\min$ (doses were $0,1.08,2.70,5.40$ and $10.08 \mathrm{~kJ}$ $\mathrm{m}^{-2}$, respectively) and PS for 0 (control), 2, 3 and 5 min (doses were $0,1.08,1.62$ and $2.70 \mathrm{~kJ} \mathrm{~m}^{-2}$, respectively) without or with turning halfway through the treatment (without opening the chamber) to ensure uniform radiation exposure. The samples were arranged on the perforated shelfs on the positions with uniform radiation, what was previously established. Each treatment was performed in triplicates. After the treatment, PT were peeled and sliced, and PT slices as well as PS were placed on a plate and stored in refrigerator at $10{ }^{\circ} \mathrm{C}$ for $24 \mathrm{~h}$. They were photographed before and after storing to visually monitor the color stability. For phenolic extraction and analysis all samples were freezedried, grounded into powder and kept on $-20{ }^{\circ} \mathrm{C}$ until extraction.

\subsection{Microbiological analysis}

Total mesophilic count, AMB, was performed according to the HRN EN ISO 48331:2013 (ISO 4833-1: 2013, EN ISO 48331:2013). Immediately after the treatment $10 \mathrm{~g}$ of sample (PT or PS) was mixed with $90 \mathrm{ml}$ peptone saline solution in a sterile stomacher bag and homogenized for 1 min using a Stomacher. Dilutions were made in peptone water as needed for plating. 


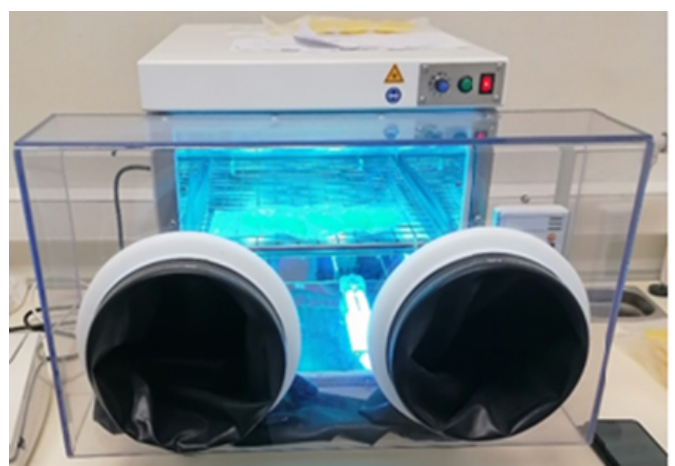

Figure 1. UV-C (UVpro EKB 100, assembled by Aura Steril, Jalkovec, Varaždin, Croatia)

Plate Count Agar (Biolife, Milan, Italy) was used as the media for $\mathrm{AMB}$ pour plate, incubated at $30 \pm 1{ }^{\circ} \mathrm{C}$ for $72 \pm 3 \mathrm{~h}$.

\subsection{Phenolic compounds}

\subsubsection{Chemicals and standards}

Methanol and formic acid were HPLC grade (Sigma Aldrich, Milano, Italy). Chlorogenic acid (CHA) and caffeic acid (CA) were purchased from Sigma-Aldrich (Steinheim, Germany) and rutin (RUT) from Acros Organics (Thermo Fisher Scientific, Geel, Belgium).

\subsubsection{Extraction of phenolic compounds}

Extraction was performed according to Elez Garofulić and co-workers (2018) with modifications. Briefly, 0,5 $\mathrm{g} \pm 0,01 \mathrm{~g}$ of potato powder was homogenized on Vortex with $5 \mathrm{ml}$ $80 \%(\mathrm{v} / \mathrm{v})$ aqueous methanol $+1 \%$ formic acid. Extraction was hold in the ultrasonic bath (Elmasonic $40 \mathrm{H}$, Elma, Germany) at $50{ }^{\circ} \mathrm{C}$ for $30 \mathrm{~min}$, followed by centrifugation at $3000 \mathrm{rpm}$ for $10 \mathrm{~min}$. Supernatant was filtrated in volumetric flask and made up to $10 \mathrm{ml}$ with a matching solvent. Extract $(1 \mathrm{ml})$ was filtered through $0.45-\mu \mathrm{m}$ pore size membrane filter and stored at $-20^{\circ} \mathrm{C}$ until analysis.

\subsubsection{UPLC MS $S^{2}$ analysis}

An Agilent series 1290 RRLC instrument (Agilent Technologies, Santa Clara, CA, USA) with an Agilent triple quadrupole mass spectrometer (6430) and an ESI ion source in the negative and positive mode (m/z 100 to 1000$)$ with the data collected in the dMRM mode was used for the identification and quantification of phenolic content with followed settings: Agilent Eclipse Plus C18 column $(100 \mathrm{~mm} \times 2.1 \mathrm{~mm}$, $1.8 \mu \mathrm{m}$ particle size), temperature $35^{\circ} \mathrm{C}$, the injection volume $2.5 \mu \mathrm{L}$, flow rate $0.3 \mathrm{~mL}$ min1 at chromatographic conditions previously described by Elez Garofulić and co-workers (2018). The eluent A contained $0.1 \%$ of formic acid and eluent $\mathrm{B}$ contained $0.1 \%$ formic acid in acetonitrile. Identification and quantification were done by related calibration curves.

\subsection{Statistical analysis}

Statistical analysis was performed using Statistica ver. 8.0 software (Statsoft Inc., Tulsa, USA). Variables were analyzed by multivariate analysis of variance (MANOVA), while differences between specific group means were determined with Tukey's HSD test. The significance level for all tests was $p \leq 0.05$.

\section{Results and discussion}

\subsection{Microbiological analysis}

Prior to UV-C irradiation, the microbial load of AMB was $3.41 \log _{10} \mathrm{CFU} \mathrm{g}^{-1}$ in PT and 3.36 $\log _{10} \mathrm{CFU} \mathrm{g} \mathrm{g}^{-1}$ in PS (Figure 2). The AMB reduction during irradiation was remarkably higher in PS in comparison with PT. Specifically, to achieve AMB reduction similar to PS, application of higher doses was required for PT. The irradiation time required to reduce AMB by $1.5 \log _{10}$ CFU g ${ }^{-1}$ in PS was $2 \mathrm{~min}$, while in PT a reduction of $1 \log _{10} \mathrm{CFU} \mathrm{g}^{-1}$ was achieved during $10 \mathrm{~min}$ irradiation, probably as a consequence of the surface topography (Koutchma et al., 2019). Turning samples during UV-C irradiation significantly influenced on the AMB in PS, but not in PT. One of the main advantages of UV-C treatment is inactivation/reduction of microbial load, attributed to the photochemical lesion induced on microorganisms' DNA and RNA, which results in the inability to regularly transcribe and replicate nucleic acids and microorganisms' cells die (Koutchma et al., 2019). 


\subsection{Phenolic content}

CHA was the most abundant phenolic compound in all samples, followed by remarkably lower content of CA and RUT (Table 1), what was in accordance to Deußer and co-workers (2012) results as well as its concentrations which were in reported ranges. UV-C treatment significantly influenced on the content of CHA and $\mathrm{CA}$ in PT and PS. Generally, increase of phenolics with the treatment time was observed, with an exception of CA in PS (Table 1). Teoh and co-workers (2016) also reported increase of total phenolic content by UV-C treatment time, which they linked with the activated phenolic biosynthesis caused by the cell damage as well as the UV-C irradiation as a stress conditions for potato tissue. On the other hand, slight CHA decrease

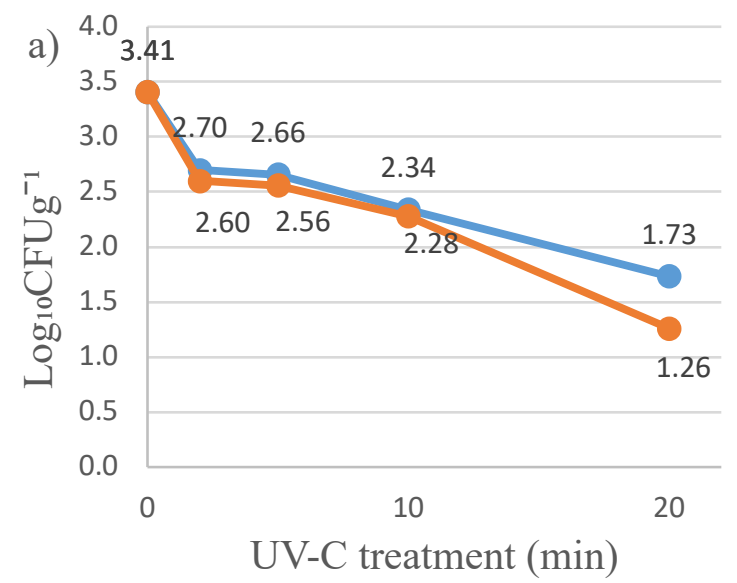

without turnning was observed with elongation of UV-C treatment, but still its contents were significantly higher compared to the untreated samples. Different enzymes showed different sensitivity to UV-C irradiation and have different roles in biochemical changes of phenolic compounds, where phenylalanine ammonia lyase could be activated by UV-C, and has an important role in phenolic biosynthesis. The polyphenol oxidase and peroxidase have a great role in enzymatic browning, particularly in the first reaction where oxidation of phenolic compounds occurs and its resistance to UV-C treatment depend upon applied doses, especially for peroxidase (Teoh et al., 2016). Also, CHA is a known substrate for enzymatic browning (Li et al., 2018).

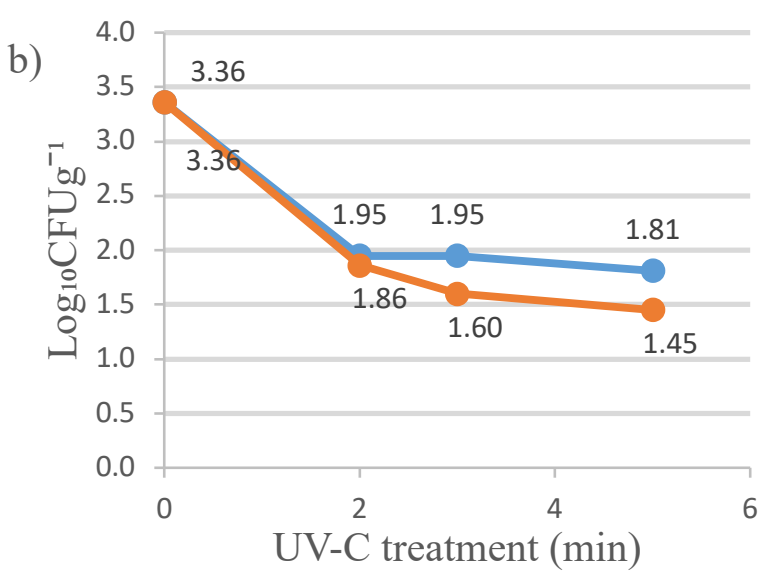

with turnning

Figure 2. The effect of UV-C treatment on aerobic mesophilic bacteria $\left(\log _{10} \mathrm{CFU} \mathrm{g} \mathrm{g}^{-1}\right)$ in potato tubers (a) and potato slices (b)

Further, phenolic content in PT was expectedly higher in comparison with PS, since potato peel contains higher amounts of phenolics (Deußer et al., 2012), and absorbed energy of UV-C light could affect certain reactions and changes of molecules (Koutchma et al., 2019) what consequently could enhance phenolic content in PT although peeled tubers were analyzed.

Turning samples halfway through the treatment significantly influenced on CA in PT and CHA in PS (Table 1), where an increase was noticed what is in accordance with previous observations that UV-C irradiation induces phenolic biosynthesis.

Nevertheless, considering the both sources of variation, treatment time and turning halfway through the treatment, contents of CHA, CA and RUT in PT, and CHA in PS were significantly affected but without uniform pattern (Table 1). Generally, PT turning caused a slight decrease of CHA and RUT as well as an increase of CA in comparison with unturned samples. The decrease of CHA was more obvious in 5 and 10 
min UV-C treatment. Content of CHA in PS increased with PS turning, where the highest increase was observed in 2 min UV-C treatment. Such different pattern could caused by the difference in topography of the tubers surface and consequently absorbed energy of UV-C light (Koutchma et al., 2019) and probably the thickness of the samples could have a certain effect on susceptibility of different enzymes included in the synthesis or decomposition of phenolic compounds (Teoh et al., 2016).

Table 1. Individual phenols ( $\mathrm{mg} 100 \mathrm{~g}^{-1}$ total solids) in UV-C treated potato influenced by UV-C treatment time and turning

\begin{tabular}{|c|c|c|c|c|}
\hline Sample & Source of variation & Chlorogenic acid & Caffeic acid & Rutin \\
\hline & UV-C treatment $(\min )$ & $\mathrm{p}<0.01 *$ & $\mathrm{p}=0.03 *$ & $\mathrm{p}=0.13$ \\
\hline \multirow{6}{*}{$\begin{array}{l}\text { Potato } \\
\text { tubers }\end{array}$} & 0 & $14.23 \pm 0.36^{\mathrm{a}}$ & $1.20 \pm 0.09^{\mathrm{ab}}$ & $1.93 \pm 0.34^{\mathrm{a}}$ \\
\hline & 2 & $22.45 \pm 0.36^{\mathrm{c}}$ & $1.51 \pm 0.09^{\mathrm{b}}$ & $2.30 \pm 0.34^{\mathrm{a}}$ \\
\hline & 5 & $20.75 \pm 0.36^{\mathrm{b}}$ & $1.20 \pm 0.09^{\mathrm{ab}}$ & $2.79 \pm 0.34^{\mathrm{a}}$ \\
\hline & 10 & $19.98 \pm 0.36^{\mathrm{b}}$ & $1.29 \pm 0.09^{\mathrm{ab}}$ & $1.57 \pm 0.34^{\mathrm{a}}$ \\
\hline & 20 & $20.12 \pm 0.36^{\mathrm{b}}$ & $1.06 \pm 0.09^{\mathrm{a}}$ & $2.57 \pm 0.34^{\mathrm{a}}$ \\
\hline & & $\mathrm{p}=0.05^{*}$ & $\mathrm{p}<0.01^{*}$ & $\mathrm{p}=0.08$ \\
\hline \multirow{4}{*}{$\begin{array}{l}\text { Potato } \\
\text { slices }\end{array}$} & 0 & $8.92 \pm 1.03^{\mathrm{a}}$ & $0.92 \pm 0.04^{b}$ & $0.89 \pm 0.24^{\mathrm{a}}$ \\
\hline & 2 & $13.58 \pm 1.03^{\mathrm{c}}$ & $0.32 \pm 0.04^{\mathrm{a}}$ & $1.83 \pm 0.24^{\mathrm{a}}$ \\
\hline & 3 & $12.11 \pm 1.03^{\mathrm{b}}$ & $0.27 \pm 0.04^{\mathrm{a}}$ & $1.58 \pm 0.24^{\mathrm{a}}$ \\
\hline & 5 & $11.78 \pm 1.03^{\mathrm{b}}$ & $0.18 \pm 0.04^{\mathrm{a}}$ & $1.27 \pm 0.24^{\mathrm{a}}$ \\
\hline & Turning & $\mathrm{p}=0.22$ & $\mathrm{p}=0.02 *$ & $\mathrm{p}=0.08$ \\
\hline \multirow{3}{*}{$\begin{array}{l}\text { Potato } \\
\text { tubers }\end{array}$} & without & $21.21 \pm 0.43^{\mathrm{a}}$ & $1.13 \pm 0.07^{\mathrm{a}}$ & $2.66 \pm 0.27^{\mathrm{a}}$ \\
\hline & with & $20.44 \pm 0.43^{\mathrm{a}}$ & $1.40 \pm 0.07^{\mathrm{b}}$ & $1.95 \pm 0.27^{\mathrm{a}}$ \\
\hline & & $\mathrm{p}<0.01^{*}$ & $p=0.49$ & $\mathrm{p}=0.22$ \\
\hline \multirow{3}{*}{$\begin{array}{l}\text { Potato } \\
\text { slices }\end{array}$} & without & $10.56 \pm 0.48^{\mathrm{a}}$ & $0.24 \pm 0.03^{\mathrm{a}}$ & $1.36 \pm 0.22^{\mathrm{a}}$ \\
\hline & with & $14.42 \pm 0.48^{\mathrm{b}}$ & $0.27 \pm 0.03^{\mathrm{a}}$ & $1.76 \pm 0.22^{\mathrm{a}}$ \\
\hline & UV-C treatment $(\min ) \times$ turning & $\mathrm{p}<0.01^{*}$ & $\mathrm{p}<0.01^{*}$ & $\mathrm{p}<0.01^{*}$ \\
\hline \multirow{9}{*}{$\begin{array}{l}\text { Potato } \\
\text { tubers }\end{array}$} & $2 \times$ without & $22.88 \pm 0.08^{\mathrm{e}}$ & $1.37 \pm 0.04^{\mathrm{b}}$ & $3.22 \pm 0.07^{\mathrm{c}}$ \\
\hline & $2 \times$ with & $22.02 \pm 0.08^{\mathrm{d}}$ & $1.64 \pm 0.04^{\mathrm{c}}$ & $1.37 \pm 0.07^{\mathrm{a}}$ \\
\hline & $5 \times$ without & $21.45 \pm 0.08^{c}$ & $1.07 \pm 0.04^{\mathrm{a}}$ & $2.26 \pm 0.07^{\mathrm{b}}$ \\
\hline & $5 \times$ with & $20.05 \pm 0.08^{\mathrm{b}}$ & $1.34 \pm 0.04^{\mathrm{b}}$ & $3.32 \pm 0.07^{\mathrm{c}}$ \\
\hline & $10 \times$ without & $21.08 \pm 0.08^{\mathrm{c}}$ & $1.02 \pm 0.04^{\mathrm{a}}$ & $2.11 \pm 0.07^{\mathrm{b}}$ \\
\hline & $10 \times$ with & $18.88 \pm 0.08^{\mathrm{a}}$ & $1.56 \pm 0.04^{\mathrm{bc}}$ & $1.04 \pm 0.07^{\mathrm{a}}$ \\
\hline & $20 \times$ without & $20.30 \pm 0.08^{\mathrm{b}}$ & $1.06 \pm 0.04^{\mathrm{a}}$ & $3.06 \pm 0.07^{\mathrm{c}}$ \\
\hline & $20 \times$ with & $19.95 \pm 0.08^{b}$ & $1.05 \pm 0.04^{\mathrm{a}}$ & $2.09 \pm 0.07^{\mathrm{b}}$ \\
\hline & & $\mathrm{p}<0.01^{*}$ & $\mathrm{p}=0.48$ & $\mathrm{p}=0.14$ \\
\hline \multirow{6}{*}{$\begin{array}{l}\text { Potato } \\
\text { slices }\end{array}$} & $2 \times$ without & $10.67 \pm 0.14_{a}$ & $0.30 \pm 0.02^{\mathrm{a}}$ & $1.89 \pm 0.31^{\mathrm{a}}$ \\
\hline & $2 \times$ with & $16.50 \pm 0.14^{\mathrm{c}}$ & $0.35 \pm 0.02^{\mathrm{a}}$ & $1.78 \pm 0.31^{\mathrm{a}}$ \\
\hline & $3 \times$ without & $10.67 \pm 0.14^{\mathrm{a}}$ & $0.27 \pm 0.02^{\mathrm{a}}$ & $1.54 \pm 0.31^{\mathrm{a}}$ \\
\hline & $3 \times$ with & $13.53 \pm 0.14^{b}$ & $0.27 \pm 0.02^{\mathrm{a}}$ & $1.62 \pm 0.31^{\mathrm{a}}$ \\
\hline & $5 \times$ without & $10.35 \pm 0.14^{\mathrm{a}}$ & $0.16 \pm 0.02^{\mathrm{a}}$ & $0.65 \pm 0.31^{\mathrm{a}}$ \\
\hline & $5 \times$ with & $13.20 \pm 0.14^{b}$ & $0.20 \pm 0.02^{\mathrm{a}}$ & $1.89 \pm 0.31^{\mathrm{a}}$ \\
\hline
\end{tabular}

Results are expressed as mean \pm SE. *Statistically significant variable at $\mathrm{p} \leq 0.05$. Different letters mean statistically different values at $\mathrm{p} \leq 0.05$. 
Table 2. Visual appearance of the samples

\begin{tabular}{|c|c|c|c|c|c|c|}
\hline \multirow[b]{2}{*}{ Turning } & \multicolumn{3}{|c|}{ Potato tubers } & \multicolumn{3}{|c|}{ Potato slices } \\
\hline & $\begin{array}{l}\text { UV-C } \\
\text { treatment } \\
\text { (min) }\end{array}$ & $\begin{array}{c}\text { Immediately } \\
\text { after } \\
\text { treatment } \\
\end{array}$ & $\begin{array}{c}\text { After } 24 \mathrm{~h} \\
\text { at } 10^{\circ} \mathrm{C}\end{array}$ & $\begin{array}{l}\mathrm{UV}-\mathrm{C} \\
\text { treatment } \\
\text { (min) }\end{array}$ & $\begin{array}{c}\text { Immediately } \\
\text { after } \\
\text { treatment }\end{array}$ & $\begin{array}{c}\text { After } 24 \mathrm{~h} \\
\text { at } 10^{\circ} \mathrm{C}\end{array}$ \\
\hline & 0 & & & 0 & & \\
\hline without & & & & & & \\
\hline with & & & & & & \\
\hline without & & & & & & \\
\hline with & & & & & & \\
\hline without & & & & & & \\
\hline with & & & & & & \\
\hline without & & & & & & \\
\hline with & & & & & & \\
\hline
\end{tabular}

\subsection{Browning susceptibility as a visual appearance}

Immediately after the treatment (PT, additionally, after peeling and cutting) and after $24 \mathrm{~h}$ storage at $10{ }^{\circ} \mathrm{C}$ samples were photographed to visually monitor the influence of UV-C light on browning susceptibility of PT and PS considering the increase of phenolic content (Table 2). The visual appearance of the samples stored for $24 \mathrm{~h}$ were in accordance with the results of the phenolic content, where samples with higher phenolic content, particularly CHA, had more visually noticeable browning, respectively (Table 2). All PT samples showed more intense browning and had higher content of phenolic compounds in comparison with PS. The appearance of PT was generally the same for all applied UV-C doses, except samples without turning which showed a little bit more pronounced browning. Also, the appearance of PS was pretty similar for all doses, but it could be observed that the slightly greater browning occurred in $2 \mathrm{~min}$ UV-C treatment.

\section{Conclusions}

The results of microbiological analysis confirmed that UV-C treatment was effective for the reduction of aerobic mesophilic bacteria in tubers and potato slices, but irradiation affected on the increase in phenolic content and consequently the sensitivity of treated potatoes to browning. Considering all obtained results (aerobic mesophilic bacteria count, phenolic content and susceptibility to browning), UV-C treatment of potato slices with the dose 1.62 $2.70 \mathrm{~kJ} \mathrm{~m}^{-2}$ and with turning could be suggested 
as the most promising treatment, but further research is required.

\section{References}

Alegria, C., Pinheiro, J., Duthoit, M., Gonçalves, E. M., Moldão-Martins, M., Abreu, M. (2012). Fresh-cut carrot (cv. Nantes) quality as affected by abiotic stress (heat shock and UV-C irradiation) pretreatments. LWT-Food Science and Technology, 48(2), 197-203.

Costa, L., Vicente, A. R., Civello, P. M., Chaves, A. R., Martínez, G. A. (2006). UV$\mathrm{C}$ treatment delays postharvest senescence in broccoli florets. Postharvest Biology and Technology, 39(2), 204-210.

Deußer, H., Guignard, C., Hoffmann, L., Evers, D. (2012). Polyphenol and glycoalkaloid contents in potato cultivars grown in Luxembourg: Food Chemistry, 135(4), 2814-2824.

Elez Garofulić, I., Zorić, Z., Pedisić, S., Brnčić, M., Dragović-Uzelac, V. (2018). UPLCMS2 profiling of blackthorn flower polyphenols isolated by ultrasound-assisted extraction. Journal of Food Science, 83(11), 2782-2789.

Erkan, M., Wang, S. Y., Wang, C. Y. (2008). Effect of UV treatment on antioxidant capacity, antioxidant enzyme activity and decay in strawberry fruit. Postharvest Biology and Technology, 48(2), 163-171.

Gonzales-Aguilar, G. A., Ayala-Zavala, J. F., De La Rosa, L. A., Ivarez-Parrilla, E. A. (2010). Preserving quality of fresh-cut product using safe technology. Journal für Verbraucherschutz und Lebensmittelsicherheit, 5(1), 65-72.

Guan, W., Fan, X., Yan, R. (2013). Effect of combination of ultraviolet light and hydrogen peroxide on inactivation of Escherichia coli $\mathrm{O} 157$ : H7, native microbial loads, and quality of button mushrooms. Food Control, 34(2), 554-559.

Gutierrez, J., Bourke, P., Lonchamp, J., BarryRyan, C. (2009). Impact of plant essential oils on microbiological, organoleptic and quality markers of minimally processed vegetables. Innovative Food Science \& Emerging Technologies, 10(2), 195-202.

Gutierrez, D. R., Chaves, A. R., Rodríguez, S. D. C. (2017). Use of UV-C and Gaseous Ozone as Sanitizing Agents for Keeping the Quality of Fresh-Cut Rocket (Eruca sativa mill). Journal of Food Processing and Preservation, 41(3), e12968.

HRN EN ISO 4833-1:2013: Microbiology of the food chain - Horizontal method for the enumeration of microorganisms - Part 1: Colony count at $30{ }^{\circ} \mathrm{C}$ by the pour plate technique

Jagadeesh, S. L., Charles, M. T., Gariepy, Y., Goyette, B., Raghavan, G. S. V., Vigneault, C. (2011). Influence of postharvest UV-C hormesis on the bioactive components of tomato during post-treatment handling. Food and Bioprocess Technology, 4(8), 1463-1472.

Jakubowski, T. (2019). Impact of UV-C irradiation of potato seed tubers on the defects in potato plant crops. Agricultural Engineering, 23(3), 71-77.

Koutchma, T., Forney, L.J. Moraru, C.I. (2019). Ultraviolet light in food technology: principles and applications (Vol. 2). (277 pages). Boca Raton London New York: $C R C$ press.

Li, L., Wu, M., Zhao, M., Guo, M., Liu, H. (2018). Enzymatic properties on browning of fresh-cut potato. IOP Conference Series: Materials Science and Engineering, 397(1), 1-7.

Ma, L., Zhang, M., Bhandari, B., Gao, Z. (2017). Recent developments in novel shelf life extension technologies of fresh-cut fruits and vegetables. Trends in Food Science \&Technology, 64, 23-38.

Maharaj, R., Arul, J., Nadeau, P. (2014). UV-C irradiation effects on levels of enzymic and non-enzymic phytochemicals in tomato. Innovative Food Science \& Emerging Technologies, 21, 99-106.

Manzocco, L., Da Pieve, S., Maifreni, M. (2011). Impact of UV-C light on safety and quality of fresh-cut melon. Innovative Food 
Science \& Emerging Technologies, 12(1), 13-17.

Pan, Y.-G., Zu, H. (2012). Effect of UV-C Radiation on the Quality of Fresh-cut Pineapples. Procedia Engineering, 37, 113119.

Rico, D., Martin-Diana, A. B., Barat, J. M., Barry-Ryan, C. (2007). Extending and measuring the quality of fresh-cut fruit and vegetables: a review. Trends in Food Science \& Technology, 18(7), 373-386.

Teoh, L. S., Lasekan, O., Adzahan, N. M., Hashim, N. (2016). The effect of ultraviolet treatment on enzymatic activity and total phenolic content of minimally processed potato slices. Journal of Food Science and Technology, 53(7), 3035-3042.

Xie, Z., Charles, M. T., Charlebois, D., Rolland, D., Roussel, D., Deschênes, M., C. Dubé, C., Khanizadeh, S. Fan, J. (2014). Preharvest exposure to UV-C radiation: impact on strawberry fruit quality. Acta Horticulture, 1079, 589-592.

Yaun, B. R., Sumner, S. S., Eifert, J. D., Marcy, J. E. (2004) Inhibition of pathogens on fresh produce by ultraviolet energy. International Journal of Food Microbiology, 90(1), 1-8.

\section{Acknowledgment}

This work was supported by the Croatian Science Foundation (grant number IP-2016-065343). 